\title{
Lakeside Communities of Small Mammals
}

\author{
Anna KOZAKIEWICZ
}

Kozakiewicz A. 1985: Lakeside communities of small mammals. Acta theriol., 30, 9: 171-191 [With 5 Tables \& 10 Figs]

Studies were made of communities of small mammals inhabiting the lakesides of Euknajno and Sniardwy lakes (Mazurian Lake District in Poland), using the material obtained by the CMR method over the period 1977-1979, in 10-day trapping series by catching animals in live-traps set in both submerged and emergent parts of the lakeside. It was found that the lakeside habitat is constantly inhabited by a community of small mammals (rodents and insectivores) and that the boundary between water and land does not form a sharply-defined limit of occurrence for land species of rodents and insectivores. In the rodents' community there were individuals caught in the submerged part of the lakeside only. From the aspect of certain characters they are the "poorer" part of the community and different populations, and are characterized by absence of lasting attachment to an area, low trappability and absence of participation in reproduction. They probably form part of the migrants living in habitats which are not typical for the given species during periods of peak population numbers. Individuals of some populations making simultaneous use both the submerged and emergent parts of the lakeside are characterized by certain characters of population dominants among Apodemus agrarius, Clethrionomys glareolus, Apodemus flavicollis - i, e. high degree of trappability and C. glareolus - largest home ranges. The home ranges of $A$. agrarius are concentrated near the water line.

[Warsaw University, Institute of Zoology, Department of Zoology and Ecology, Krakowskie Przedmieście 26/28, 00-927 Warszawa, Poland]

\section{INTRODUCTION}

Lakes and ponds are surrounded by an area which may be covered with water or left exposed, depending on the water level. In the case of lakes this area, together with the adjacent land area, periodically washed by waves, and the submerged area, sporadically exposed by wave movement, in Pieczyńska's opinion (1972) constitute the eulittoral zone. This is a transitional zone between the land habitat surrounding the lake and the lake littoral, characterized by specific physical and chemical conditions (Pieczyńska, 1972, 1975).

Conditions in the eulittoral zone habitat create the opportunity for development of specific plant associations and animals communities. These communities often constitute a mixture of species characteristic of this type of habitat, and also of typically land and typically aquatic species, living only temporarily in the eulittoral zone. 
One of the components using the lakeside zone is a community of small mammals consisting mainly of typically land species (cf. e. g., Bauer, 1960). Other papers have supplied data on the occurrence and some elements of the ecological structure of species of small mammals occupying the edges of lakes and ponds (Karaseva et al., 1957; Zejda, 1967).

The most comprehensive treatment in literature of problems connected with the occurrence of small mammals in the lakeside zone are to be found in papers on the edge zone of fishponds in Czechoslovakia. In addition to an ecological description of the communities examined (Pelikán, 1975; Pelikán \& Hodkova, 1977; Pelikán, 1978) they include chiefly problems connected with production and energy flow through populations of small mammals (Pelikán, 1975), and also the composition of the food of different species of small mammals (Holišova, 1972, 1975; Obrtel, 1975).

The purpose of the present paper is to give an ecological description of communities of small mammals occupying two different types of lakeside and of groups of small mammals making use of different parts of the lakeside (eulittoral zone).

\section{STUDY AREA, METHODS AND MATERIAL}

The studies were carried out in the neighbourhood of Mikolajki (Mazurian Lake District in Poland). The study areas included dry and submerged parts of the lakeside zones of Euknajno and Sniardwy Lakes. In both cases that part of the zone which during the experiment was constantly above water, was included in the studies. This part is, however, periodically covered with water in other years, and thus in accordance with Pieczyńska's classification (1972) belongs to the eulittoral zone.

The zone which was constantly emergent was covered by a forest association including alder, with a considerable percentage in the herb layer of elements from the Molinio-Arrhenatheretea class. By the side of Lake Euknajno this part passed into a zone constantly submerged during the experiment, covered with osier-beds (incompletely developed Salicetum pentandro-cinereae association) with a herb layer composed chiefly of rush elements (Phragmitetea class). Further on there was also a submerged zone covered by reeds (Phragmitetum association) mixed with aquatic plants (Lemnetea and Potamogetonetea classes). The distribution of different plant associations was thus of a zonal character. There were only slight fluctuations in water level. During the study period both parts of the eulittoral zone under water in spring, summer and autumn were covered with ice and a thick layer of snow in winter. The distribution of plant associations by Lake Sniardwy was not as distinctly zonal in character as by Lake Euknajno. In the middle part of the study area patches of osier beds and patches of Calamagrostis neglecta occurred alternately with a considerable percentage of species of the following classes: Molinio-Arrhenatheretea and Scheuchzerio-Caricetea fuscae. Fluctuations in water level in the lake caused periodical flooding or exposure of this part of the 
tulittoral zone. The part constantly under water was covered by reeds. The eulittoral zone of Lake Sniardwy was more diversified from the phytosociological aspect than that of Lake Euknajno.

The lakeside of Lake Łuknajno was surrounded by an extensive stretch of agricultural areas: meadows and fields. Potatoes or maize were grown in the latter. The lakeside was connected with shelter belts, while that of Lake Sniardwy from the land side was adjacent to a large stretch of wooded land (partly marshy alder wood, partly pine forest).

The live-traps were set singly in the area on permanent sites, forming a grid $15 \times 15 \mathrm{~m}$, and were baited with oat grain. On sites in the immersed areas the traps were set on special stands keeping the trap immediately above water level.

The lakeside area of Lake Łuknajno included in the studies in spring, summer and autumn was 2.8 ha in extent. In all winter seasons the istudy area was increased to $3.3 \mathrm{ha}$, setting more traps in that part of the lakeside zone which was under water in otherseasons. In the case of Lake Sniardwy, on account of the very considerable seasonal fluctuations in water level and consequent differences in the possibility of reaching different part of the lakeside, the study area varied in different seasons from 0.9 ha to 1.8 ha in extent.

Studies were carried out from 1977-1979 in three or four 10-day trapping series Jver the course of each year - by Lake Euknajno - in winter (February), spring (April), summer (June-July), autumn (September) 1977 and 1978, and in winter (February) 1979: by Lake Sniardwy - in summer (July), autumn (September) 1977: spring (April), summer (June-July) and autumn (September) 1978 and in spring (April-May 1979).

The CMR method was used to collect material. Traps were inspected twice daily, in the morning and evening. The date, place of capture, species, individual number, weight read from dynamometric scales with accuracy to $1 \mathrm{~g}$, sex and data on sexual activity were recorded for each capture of an animal. Males with distinctly enlarged testes and females with an open vagina, visible signs of pregnancy, post-copulation plug or lactating were taken as sexually active.

Distinction was made between newly-marked individuals - caught for the first time and marked in the given study season, and those marked previously - during one of the preceding study seasons.

If the individual was caught more than once during a trapping series, the mean weight was calculated as the arithmetical mean of all weights of the animal found during the 10-day trapping period. The mean weight of corresponding groups was found as the arithmetical mean of the weight of all individuals belonging to the given group, omitting pregnant females.

The mean number of captures of individuals belonging to a given group during the course of the whole 10-day trapping series was taken as a measure of the trappability of groups of individuals.

In calculations of the size of home ranges the elliptical home range model was used (Mazurkiewicz, 1969, 1970), since this method makes it possible to define home ranges only for animals caught five or more times during one trapping series. This method was also used for defining the centres of home ranges. When analyzing the distribution of centres of home ranges in the study area, the area was divided into three zones: aquatic - completely flooded by water, border a thirty-metre border at the waters edge, and completely dry land not flooded by water. 
For description and comparison of the animals living in different eulittoral zones the individuals caught were divided into three groups: (1) the group termed "land" (L), to which individuals caught solely in the dry part of the lakeside during the given trapping series were allocated; (2) the group termed "water" (W), to which individuals caught in a given trapping series in either completely flooded or very water lagged parts of the lakeside were allocated, that is, parts in which the animals had no opportunity of digging burrows; (3) The group termed "land-water" (L-W), which included animals caught simultaneously in both parts of study plot during the given trapping series.

A separate description has been given of groups of animals using different zones of the lakeside in winter, on account of the totally different conditions prevailing in the lakeside at the time, as compared with other seasons (ice cover on areas covered by water in other seasons). For the sake of conveniance, groups of animals were segregated in the same way as in other seasons. Animals which were caught in winter in areas which were covered by water in other seasons were allocated to the "water" group, to the "land" group - animals caught in emergent areas in other seasons and "land-water" - animals caught in both these areas.

Calculation was made of the limit of confidence for all the arithmetical means found. The isignificance of differences between mean values was estimated by means of the $t$-Student test (with $p=0.05$ ), previously using the $F$-Fisher test to estimate equality of variances.

Table 1

Number of small mammals caught in the lakeside zone of Lakes Euknajno and Sniardwy.

\begin{tabular}{|c|c|c|}
\hline & Łuknajno Lake & Sniardwy Lake \\
\hline \multicolumn{3}{|l|}{ RODENTIA } \\
\hline Clethrionomys glareolus (C. g.) & 267 & 190 \\
\hline Apodemus agrarius (A. a.) & 138 & 93 \\
\hline Apodemus flavicollis (A. f.) & 55 & 39 \\
\hline Micromys minutus (M. m.) & 15 & 46 \\
\hline Microtus agrestis (M. ag.) & 8 & 0 \\
\hline Microtus arvalis (M. a.) & 5 & 9 \\
\hline Microtus oeconomus (M. o.) & 0 & 46 \\
\hline Mus musculus (M. ms.) & 4 & 7 \\
\hline Total & 487 & 415 \\
\hline \multicolumn{3}{|l|}{ INSECTIVORA } \\
\hline Sorex araneus (S. a.) & 117 & 80 \\
\hline Sorex minutus (S. m.) & 13 & 2 \\
\hline Neomys fodiens & 15 & 8 \\
\hline Total & 145 & 90 \\
\hline
\end{tabular}

A total of 902 small rodents were caught, the animals being trapped a total of 4350 times in the two study areas during the whole experiment (Table 1). In addition 235 individuals of 3 species of insectivores were caught (Table 1). In view, however, of the very high mortality of these animals in live-traps and the fact that live-traps suitable for rodents are unsuitable for insectivores (Pucek, 1969) only analysis in their places of capture was made. 


\section{RESULTS}

\subsection{Description of Small Rodent Communities in the Two Lakesides}

The dynamics of density for rodents living on eulittoral zone of Lake Euknajno varied in a different way in successive study years. In the first year of studies density increased slightly from winter to spring, was maintained on the same level from spring to summer, increased considerably up to autumn and decreased up to the winter of 1978. In the subsequent (1978) year of studies density did not alter from winter to spring, but later increased up to summer. Further changes in density were similar in character to those in the first study year (Fig. 1). On the side of Lake Sniardwy the density of the small rodent community chan-

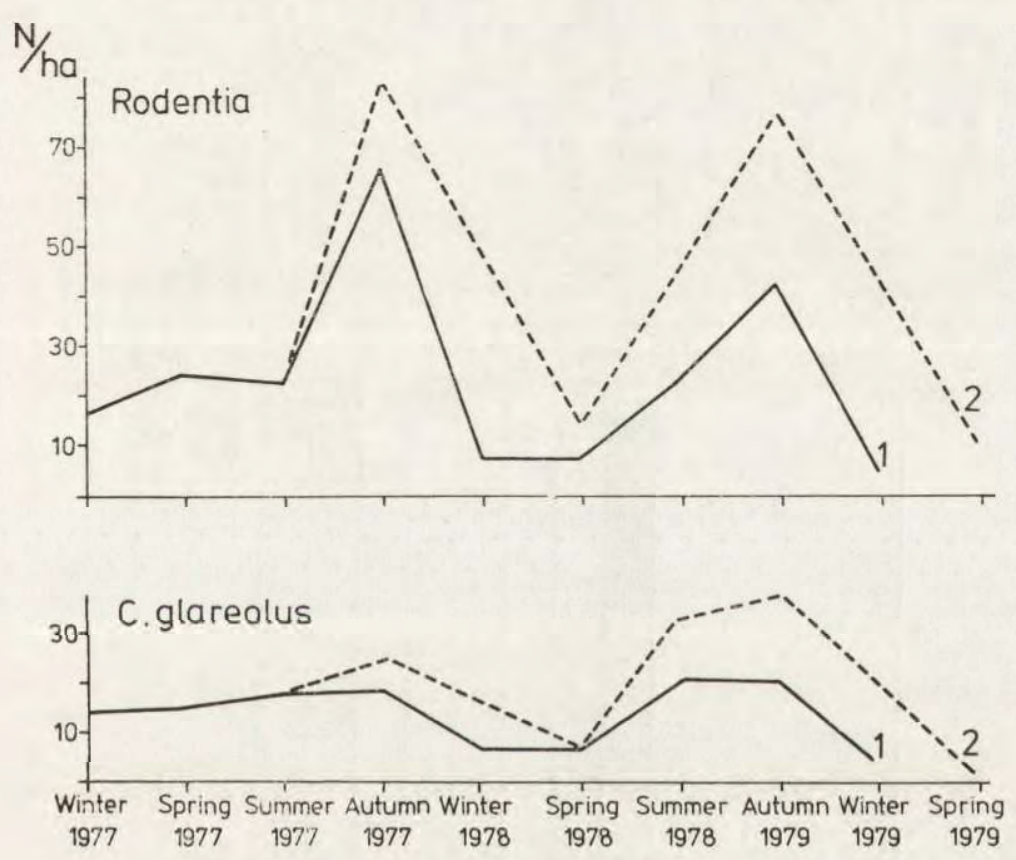

Fir. 1. Variations in numbers of a small rodent community and population of

C. glareolus in the eulittoral zone of Lakes Euknajno (1) and Sniardwy (2).

ged in a similar way in both study years: it increased from summer to autumn, then decreased markedly from autumn to spring. In the second study year density increased from spring to summer. Density of rodents on the edge of Lake Sniardwy was similar in the corresponding study seasons (summer 1970) or higher (remaining seasons) in comparison with the density of the community on the edge of Lake Euknajno (Fig. 1).

C. $g$. is a species constantly occurring in the study areas. On the edge 
of Lake Sniardwy $M$. o. was also constantly present, whereas it did not occur at all in the community by Lake Euknajno. The remaining species appeared periodically on the edges of both lakes, chiefly $A$. a., which especially in autumn attained a high percentage in the communities until it reached numerical domination over the other species of small rodents

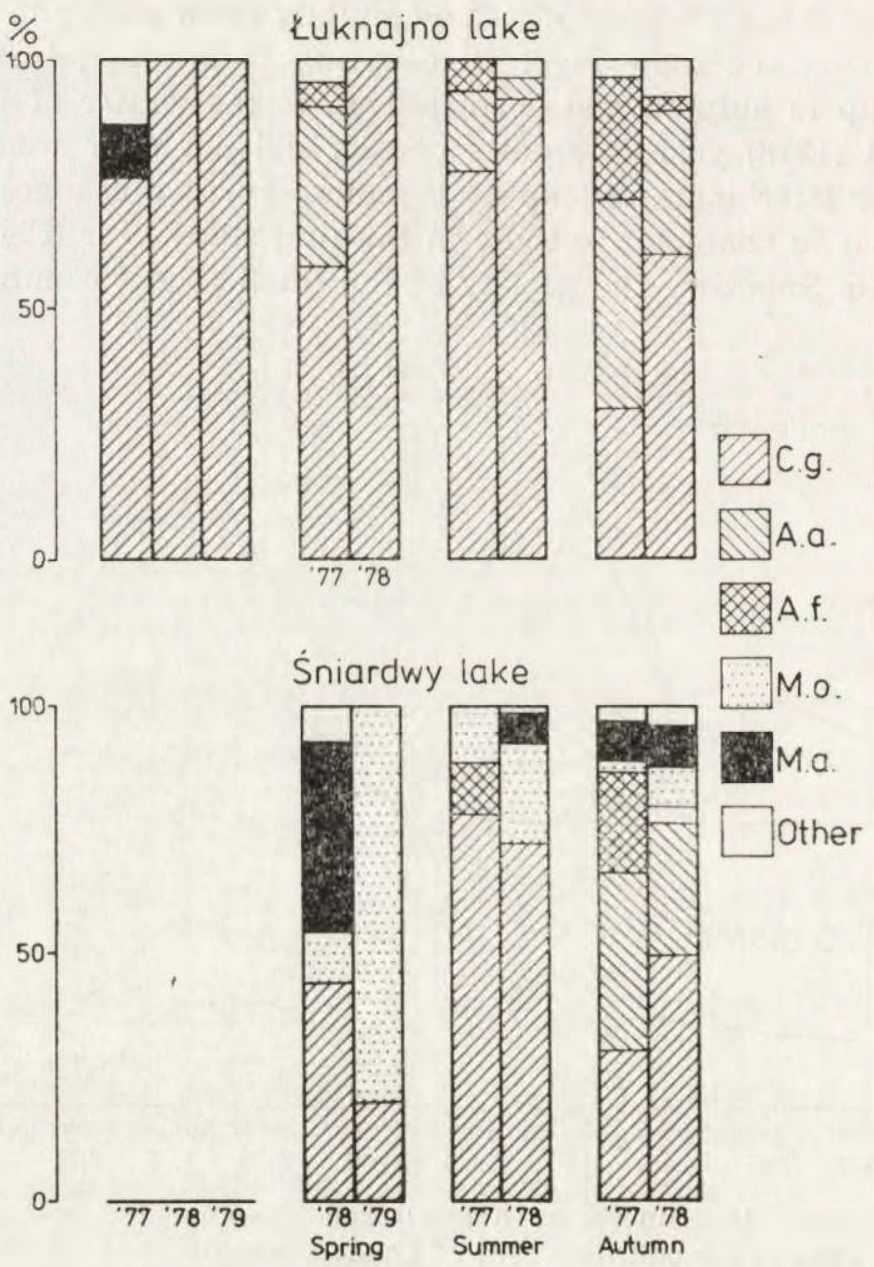

Fi 3. 2. Percentages of different species in the small rodent community in different study seasons in the lakeside (eulittoral zone) of Lakes Euknajno and Sniardwy.

(autumn 1977). A. a. was in addition present in the community by Lake Łuknajno in summer in both study years and in spring 1977 (Fig. 2). In the summer of 1977 and in autumn in both study years $A$. f. was present in both study areas, but formed a considerable percentage of the community only in the autumn of 1977. A. f. occurred sporadically 
in the spring of 1977 by Lake Łuknajno. In spring and summer of the second study year and in autumn in both years $M$. ag. also occurs by Lake Sniardwy, forming a large percentage of the community in spring 1978. M. ag. occurred only in the winter and spring 1977 by Lake Euknajno. The remaining species of small rodents occurred sporadically on the edges of both lakes (Fig. 2).

In the majority of the study seasons the greatest percentage (up to $100 \%$ ) in both study areas in the community of small rodents was formed by $C$. $g$. It was only in autumn in the first study year in both study areas that $A$. a., and in the spring of 1979 by Lake Sniardwy, M. o., reached a higher percentage than bank voles in the small rodent community (Fig. 2).

The number of species found in both lakeside areas varied in different seasons, fluctuating from one to seven by Lake Łuknajno and from two to seven by Lake Sniardwy (Table 2). The value of the Shannon-Wiener

Table 2

Comparison of the number of species (N) and values of the Shannon-Wiener (Sh-W) index for communities of small rodents in the lakeside zone of Lakes Euknajno and Sniardwy.

\begin{tabular}{|c|c|c|c|c|c|c|c|c|c|c|}
\hline & & Winte & & & Sprin & & $\mathrm{Su}$ & ner & & \\
\hline & 77 & '78 & '79 & '77 & 78 & '79 & 77 & '78 & & '78 \\
\hline & & & & knajı & Lak & & & & & \\
\hline $\mathrm{N}$ & 4 & 1 & 1 & 6 & 1 & & 3 & 4 & 7 & 6 \\
\hline Sh-W & 1.1 & 0 & 0 & 1.4 & 0 & & 0.9 & 0.5 & 1.9 & 1.5 \\
\hline & & & & iardy & Lak & & & & & \\
\hline $\mathrm{N}$ & & & & & 4 & 2 & 3 & 5 & 7 & 7 \\
\hline Sh-W & & & & & 1.7 & 0.7 & 1.0 & 1.2 & 2.1 & 2.0 \\
\hline
\end{tabular}

species diversity index varied from 0 to 2 (Table 2). In corresponding study seasons the Shannon-Wiener index attained higher values for the community by Lake Sniardwy than that by Lake Euknajno (Table 2).

\subsection{Density of the Most Numerous Rodent Species}

Variations in density of the $C$. $g$. population occurring by Lake Sniardwy were similar in character to those of the whole community of small rodents in this area. It was only from summer to autumn in the first study year (1977) that increase in the C. g. population was far lower than for the whole community. In the lakeside of Lake Łuknajno the C. $g$. population density increased slightly in the first study year (from winter to autumn) to reach a level of 20 individuals/hectare in the autumn of 1977 . Later, up to the winter of 1978 , population density distinctly 
decreased and was maintained on the same level (about 7 individuals/ha) up to the spring of 1978 , after which in the summer of 1978 there was an increase in density to a level of 20 individuals/ha. This level was maintained up to the autumn of 1978, after which it decreased considerably up to the winter of 1979 (Fig. 1). In corresponding study seasons density of the $C$. $g$. population was either equal in both study areas or attained higher values for the population by Lake Sniardwy than for that by Lake Euknajno. In general in the lakeside zone of Lake Euknajno there were far lesser fluctuations in density of the $C . g$. population than in the corresponding zone of Lake Sniardwy (Fig. 1).

Peak numbers of $A$, a. occurred in autumn. By Lake Sniardwy these were the only seasons in which $A$, s. occurred at all. The density of this

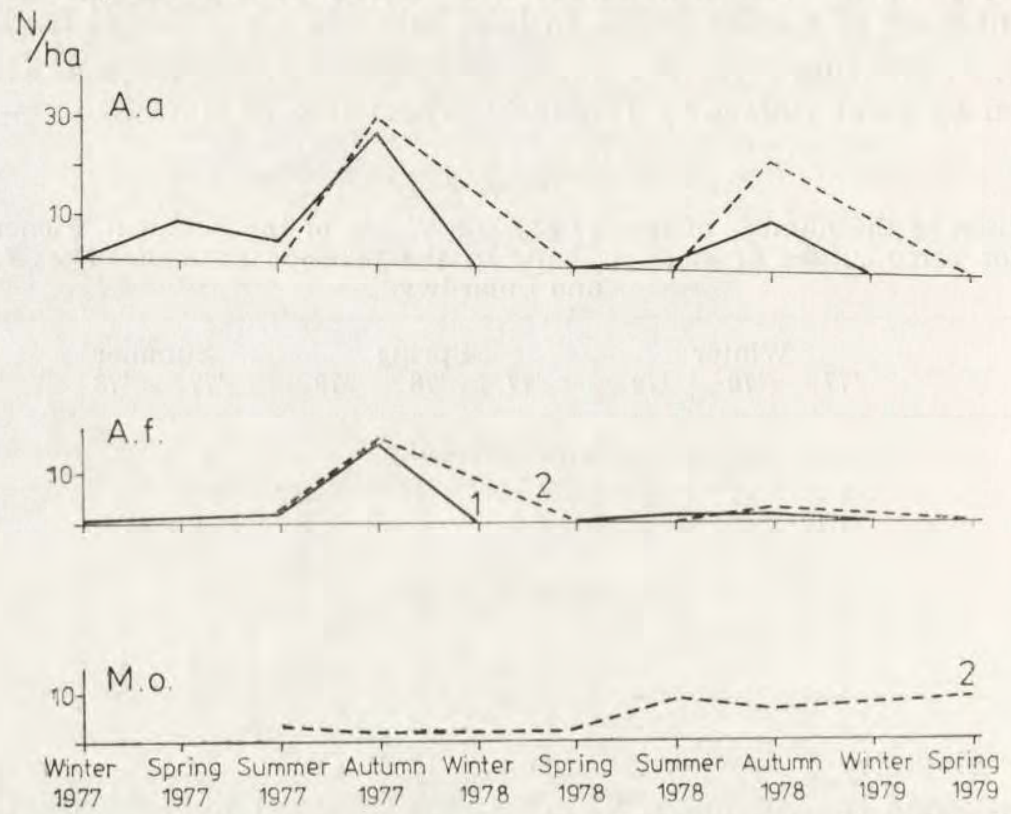

Fig. 3. Variations in numbers of a population of A. agrarius (A.a.), A. flavicollis (A.f.) and $M$, oeconomus (M.o.) in the eulittoral zone of Lakes Euknajno (1) and Sniardwy (2).

species by Lake Łuknajno was very low in other seasons. On both study areas $A$. $f$. occurred very densely only in the autumn of the first study year. In all other seasons it either did not occur at all, or occurred sporadically (Fig. 3). The $M$. o. population by Lake Sniardwy reached only low densities throughout the whole experiment. The population density of this species changes from about $2-3$ individuals/ha in the first study year to about 9 individuals/ha in spring 1978, and was maintained on the same level up to the spring in the next year (Fig. 3). 


\subsection{Distribution of Centres of Home Ranges}

The majority the centres of home ranges of $C . g$. individuals in both study areas were situated in completely dry parts, but did not exhibit congregation in any special places. In the case of $A$. $a$. such centres are concentrated in both study areas in the border zone just by the water line. By Lake Sniardwy 16 out of 21 and by Lake Euknajno 18 out of 22 such centres of the home ranges of $A$, $a$. were situated in this border zone (Fig. 4).

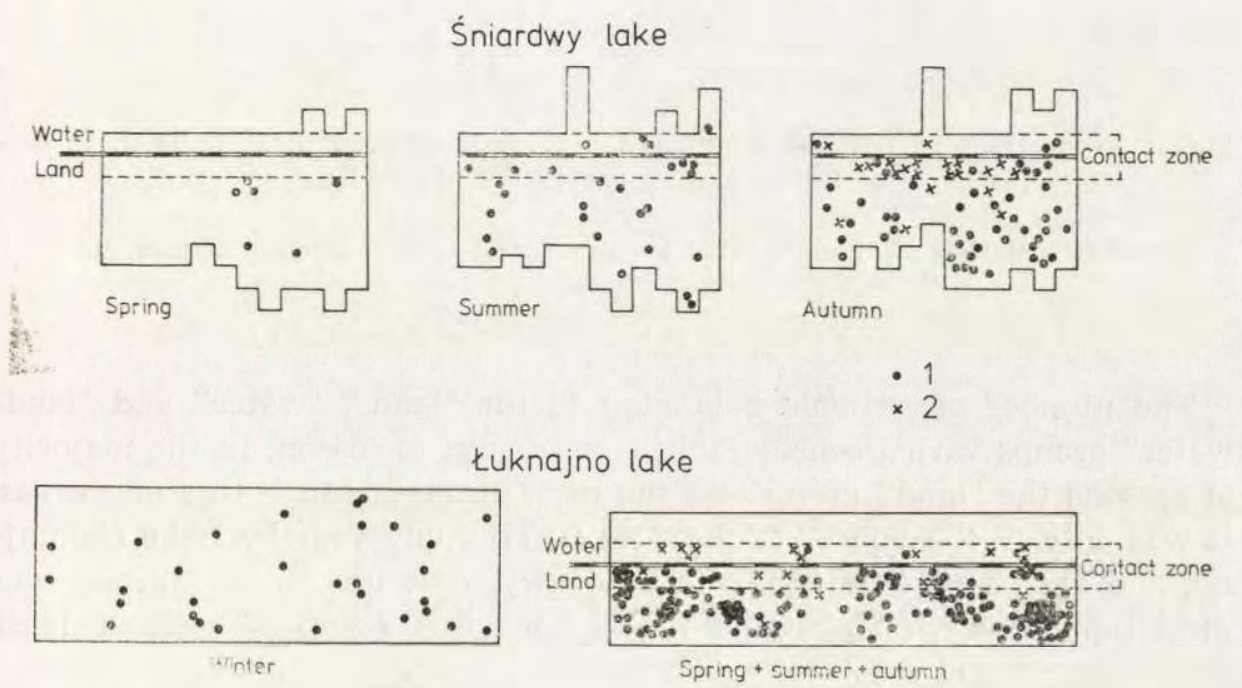

Fig. 4. Distribution of centres of the home ranges of C. glareolus (1) and A. agrarius (2) in the study areas.

\subsection{Proportion of Old and Newly-marked Individuals in the Rodent Populations}

Individuals marked in the given season predominated in the C. $g$. population in both lakesides. By Lake Euknajno it was only in the winter of 1978 and 1979 and in the spring of 1978 that there was a greater proportion of individual marked in preceding seasons (Fig. 5). By Lake Sniardwy in the spring of 1979 only 2 representatives of C. g. were caught and both had been marked previously. In both study areas the great majority of individuals of all the other species of rodents remained for one study season only. An exception to this was formed by one representative of $A$. $a$. by Lake Łuknajno, marked in spring 1977 and caught in the area in the summer and autumn of 1977, and two representatives of $M$. o. from the community by Lake Sniardwy, marked in one study season and caught again in subsequent seasons. 


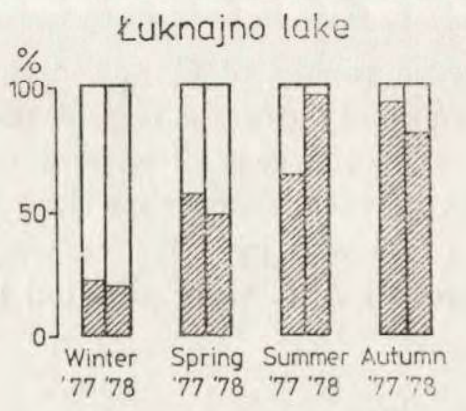

Śniardwy lake

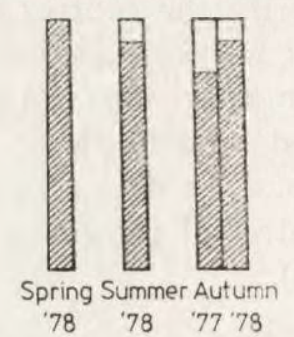

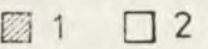

Fig. 5. Proportions of newly-marked and previously-marked individuals in C. glareolus populations. 1 - newly-marked, 2 - previously-marked.

\subsection{Description of "Land", "Water", and "Land-water" Groups of Rodents}

\subsubsection{Seasonal Variations in the Number of Rodents in Groups}

The number of animals belonging to the "land", "water" and "landwater" groups varied considerably from season to season. In the majority of seasons the "land" group was the most numerous in both study areas. It was only in the winter of the first (1977) study year by Lake Euknajno, and spring of 1979 by Lake Sniardwy, that the "water" group was most numerous. In the remaining seasons this group was either least numerous or did not occur, while the "land-water" group is usually intermediate in respect of numbers (Table 3 ).

\section{Table 3}

Comparison of number of representatives of small rodents belonging to the following groups: "land" (L), "land-water" (L-W) and "water" (W) in different study seasons in the lakeside zone of Lakes Euknajno and Sniardwy. W, Winter; Sp, Spring; S, Summer; A, Autumn

\begin{tabular}{|c|c|c|c|c|c|c|c|c|c|c|}
\hline Group & $\begin{array}{l}\text { W } \\
\text {,77 }\end{array}$ & $\begin{array}{l}\text { Sp } \\
{ }^{\prime} 77\end{array}$ & $\underset{77}{\mathrm{~S}}$ & $\stackrel{\mathrm{A}}{{ }^{7} 77}$ & $\begin{array}{l}\text { W } \\
78\end{array}$ & $\begin{array}{l}\text { Sp } \\
\text { '78 }\end{array}$ & $\stackrel{\mathrm{S}}{\mathrm{S}}$ & $\begin{array}{r}\text { A } \\
{ }^{7}\end{array}$ & $\begin{array}{l}\text { W } \\
\text { '79 }\end{array}$ & $\begin{array}{l}\text { Sp } \\
79\end{array}$ \\
\hline \multicolumn{11}{|c|}{ Euknajno Lake } \\
\hline $\begin{array}{l}\mathrm{L} \\
\mathrm{L}-\mathrm{W} \\
\mathrm{W}\end{array}$ & $\begin{array}{l}16 \\
10 \\
31\end{array}$ & $\begin{array}{l}41 \\
13 \\
16\end{array}$ & $\begin{array}{r}57 \\
7 \\
0\end{array}$ & $\begin{array}{r}110 \\
45 \\
29\end{array}$ & $\begin{array}{r}18 \\
0 \\
5\end{array}$ & $\begin{array}{r}17 \\
7 \\
3\end{array}$ & $\begin{array}{r}28 \\
27 \\
9\end{array}$ & $\begin{array}{l}40 \\
22 \\
30\end{array}$ & $\begin{array}{r}14 \\
0 \\
0\end{array}$ & \\
\hline
\end{tabular}

\section{Sniardwy Lake}

\begin{tabular}{lrrrrrr} 
L & 27 & 99 & 11 & 44 & 76 & 3 \\
L-W & 5 & 34 & 7 & 29 & 33 & 1 \\
W & 3 & 18 & 1 & 10 & 29 & 6 \\
\hline
\end{tabular}


In the "land" group in both study areas the greatest percentage was formed by $C$. g., particularly in the community by Lake Euknajno. $A$. $a$. and $A$. f. also occurred there in this group, forming less than $20 \%$ of it (Fig. 6). C. g. formed only $54 \%$ in the "land" group of the community by Lake Sniardwy, while 4 species formed $43 \%$ of the group: A. f., A. a., $M$. ag., and $M$. o. occurring in approximately equal numerical proportions (Fig. 6A).

The species composition of the "land" group varied in different seasons. C. g. decidedly dominated numerically in winter. In spring its percentage

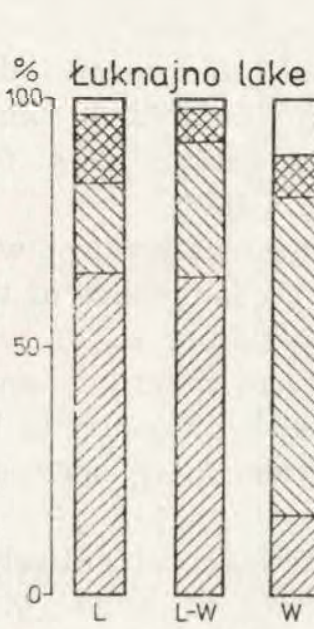

A

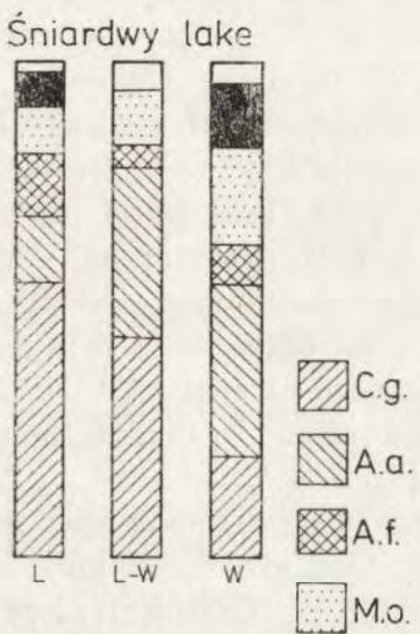

B
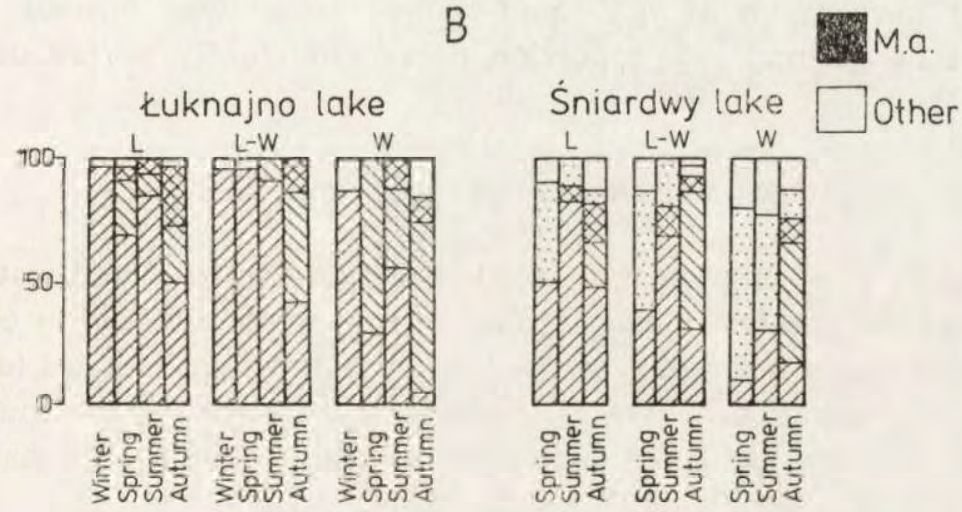

Fig. 6. Percentage of rodent species in the following groups: "land", (L), "land-water" (L-W) and "water" (W) totalled for spring, summer and autumn (A) and in different phenological seasons (B) in both the lakesides examined. 
decreased and the following additionally entered the composition of the group: $A$. $a$. by Lake Łuknajno, $M$. o. by Lake Sniardwy. In summer the percentage of $C . g$. in the "land" group increased in comparision with spring. The remaining species occurred sporadically. In autumn the percentage of $C$. g. in the group decreased in both study areas to about $50 \%$ and its place was taken chiefly by $A, a$, and $A$. f. (Fig. 6B).

$A$. $a$, dominates numerically among rodents belonging to the "water" group in both study areas. C. $g$. and $A$. $f$. also enter into the composition of this group. $M$. o. formed a considerable percentage of the "water" group by Lake Sniardwy (Fig. 6A).

C. g. decidedly predominated numerically in the "water" group in winter. In spring its percentage in the group decreased chiefly in favour of $A, a$. by Lake Łuknajno and $M . o$. by Lake Sniardwy. In summer the proportion of $C$. $g$. in the group increased, this species dominating) numerically by Lake Euknajno, whereas the numerical domination of $M$. o. was maintained by Lake Sniardwy. In autumn $A$. a. formed the greatest proportion in the "water" group (Fig. 6B).

In the third "land-water" group, the highest percentage was formed by $C . g$. in both study areas. The numerical predominance of this species over others was more distinct by Lake Łuknajno. A. a., was a subdominant, its percentage being higher by Lake Sniardwy and close to the percentage formed by $C . g . A$. f. occurred additionally in both study areas, and $M$. o. by Lake Sniardwy. The remaining species occurred sporadically (Fig. 6).

In winter the "land-water" group consisted almost entirely of C. g. In spring, by Lake Łuknajno, C. $g$. also dominated, but $C$. $g$. and $M$. $o$. co-dominated by Lake Sniardwy. In summer in the two study areas the greatest percentage in the "land-water" group was formed by C. g., whereas in autumn its proportion decreased chiefly in favour of $A$. a. (Fig. 6).

\subsubsection{Mean Number of Captures per Individual}

In the C. g. population individuals belonging to the "land-water" group exhibited the greatest mean number of captures/individual in comparison with individuals belonging to the "land" and "water" groups (differences statistically significant). On an average more captures per individual of C. g. took place by Lake Euknajno in the "land" group than per individual from the "water" group (differences statistically significant), whereas by Lake Sniardwy C. g. from the "land" and "water" groups did not differ significantly in the average number of captures per individual (Fig. 7). 
In $A$. $a$. population on both study areas the greatest number of captures per individual occurred on an average in the "land-water" group, lower in "land" group and lowest - in "water" group (differences: statistically significant) (Fig. 7).

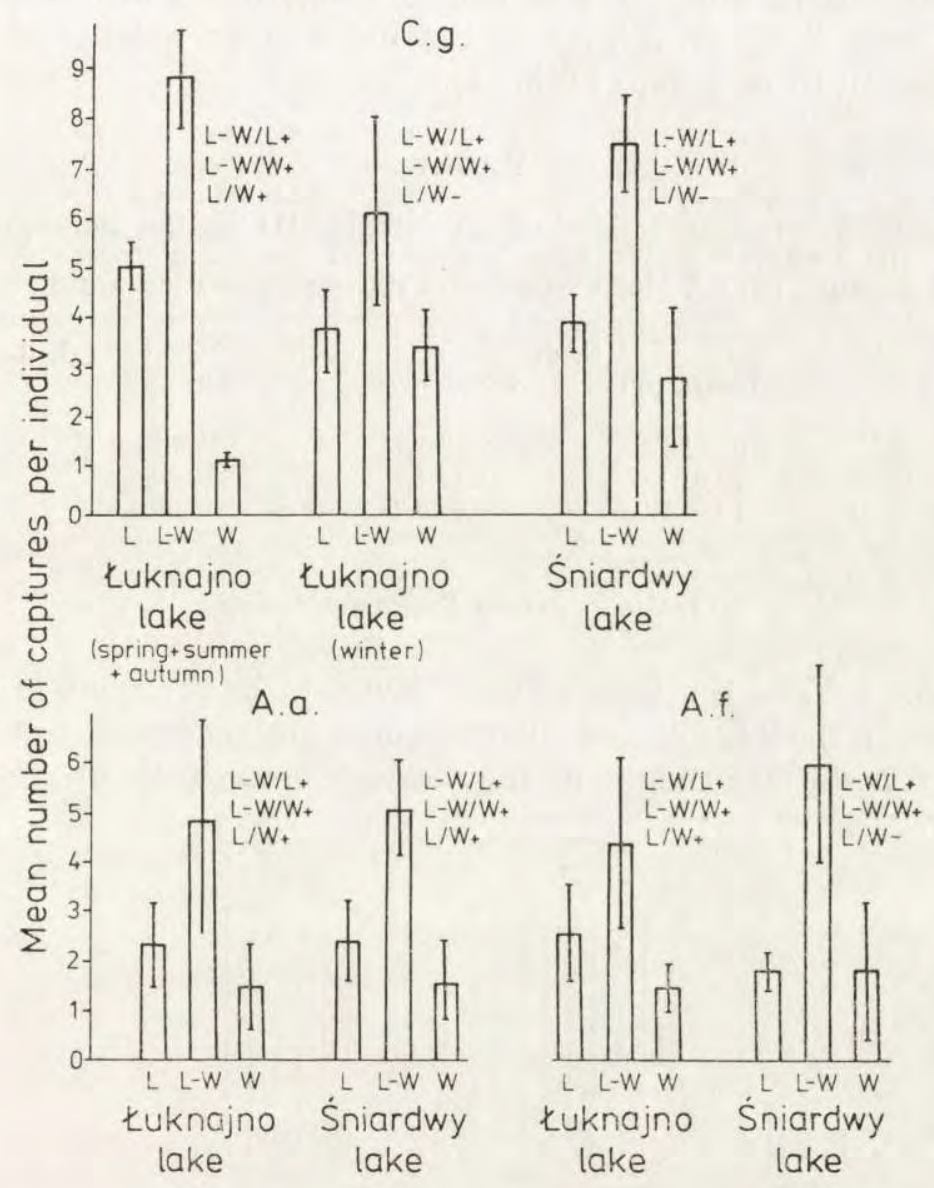

Fig. 7. Comparison of mean number of captures per individual from the "land" (L), "land-water" (L-W) and "water" (W) groups for the C. glareolus (C.g.), A. flavicollis (A.f.) and A. agrarius (A.a.) populations. Differences statistically significant $(+)$ and non-significant $(-)$ are marked as shown.

In the $A . f$. population by Lake Euknajno the greatest number of captures per individual occurred on an average in the "land-water" group, and the lowest in the "water" group (differences statistically significant). These mean values did not differ in the "water" and "land" groups by Lake Sniardwy, but individuals from the "water-land" group. 
exhibited a higher average number of captures than for the two preceding groups (Fig. 7).

\subsubsection{Mean Body Weight of Animals}

In neither study area were statistically significant differences found for $C$. g. and $A$. a., in respect of the mean body weights of animals belonging to all three groups (Table 4 ).

Table 4

Comparison of mean body weight of animals ( \pm S.D.) in the following groups: "land" (L), "land-water" (L-W) and "water" (W) for C. glareolu.s (C. g.) and $A$. agrarius $(A, a$.$) . Mean values and standard deviation are given.$

\begin{tabular}{lcccr}
\hline Group & \multicolumn{2}{c}{ C. $g}$. & \multicolumn{2}{c}{ A. $a}$. \\
& Euknajno & Sniardwy & Łuknajno & Sniardwy \\
\hline L & $17.3 \pm 0.8$ & $18.6 \pm 0.5$ & $17.7 \pm 1.2$ & $19.6 \pm 0.9$ \\
L-W & $19.8 \pm 1.0$ & $18.1 \pm 1.4$ & $17.4 \pm 0.7$ & $19.6 \pm 0.7$ \\
W & $18.5 \pm 0.9$ & $19.2 \pm 0.7$ & $18.0 \pm 0.5$ & $20.4 \pm 1.4$ \\
\hline
\end{tabular}

\subsubsection{Proportion of Pregnant Females}

Less than $20 \%$ of the females were found to be pregnant in the C. $g$. population in the "land" and "land-water" groups, while not a single pregnant female was caught in the "water" group (Fig. 8).

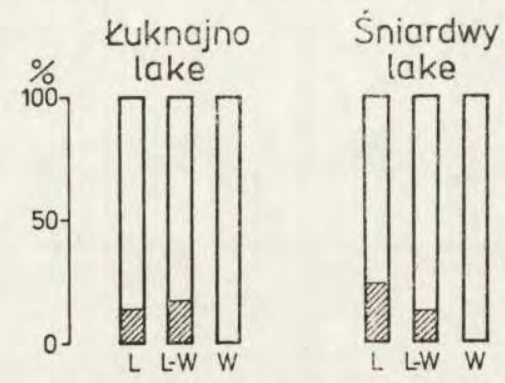

Fig. 8. Percentage of pregnant females (shaded) in the "land" (L), "land-water"

(L-W) and "water" (W) groups in C. glareolus populations.

3.5.6. Proportion of Animals Newly-marked or Marked in Previous Seasons

In both $C$. $g$. populations the percentage of previously-marked animals was similar in both the "land" and "land-water" groups, while the "water" group consisted solely of newly-marked individuals (Fig. 9). Although three individuals from the "water" group remained until the subsequent season, they transferred to the "land" group. 

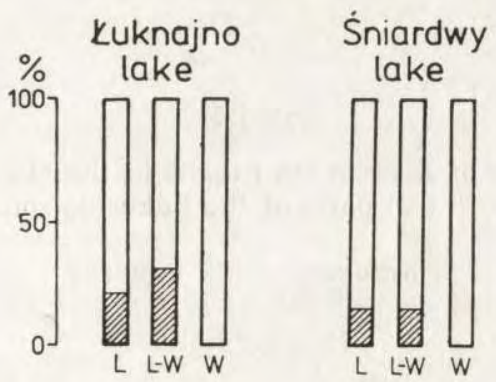

Fig. 9. Percentage of newly-marked and previously-marked (shaded bars) in the "land" (L), "land-water" (L-W) and "water" (W) groups in C. glareolus populations.

\subsubsection{Size of Home Ranges}

On both lakesides individuals from the $C$. $g$. population belonging to the "land-water" group had significantly greater average home ranges than individuals from the "land" group (Fig. 10). Individuals from the "water" group were caught, in the majority of cases, less than five times, and thus with the method used there was no possibility of calculating the size of their home ranges.

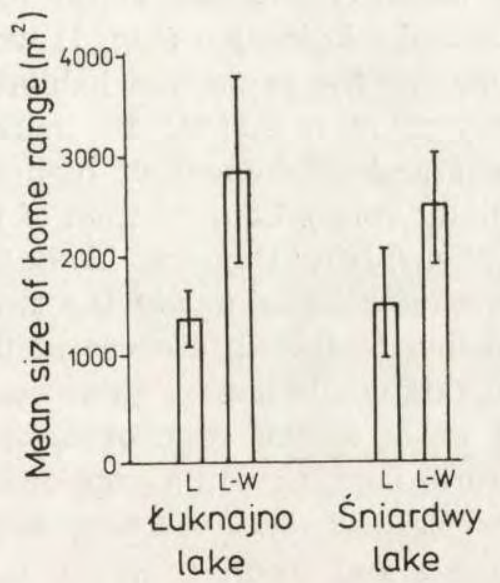

Fig. 10. Comparison of mean sizes of home ranges of C. glareolus from the "land" (L) and "land-water" (L-W) groups.

\subsection{Places on which Insectivores Were Caught}

Among the three species caught on both study areas the majority of $S$. $a$. and $S$. $m$. were caught in dry areas, although they also were caught 
in areas flooded by water. Representatives of $N . f$. were caught chiefly in immersed areas (Table 5).

Table 5

Total number of Insectivora caught in the "land" (L) and "water" (W) parts of the Lakeside zones.

\begin{tabular}{cccc}
\hline Group & S. araneus & S. minutus & $N$. fodiens \\
\hline \multicolumn{4}{c}{ Euknajno Lake } \\
W & 38 & 9 & 13 \\
L & 79 & 4 & 2 \\
& \multicolumn{4}{c}{ Sniardwy Lake } \\
W & 27 & 0 & 8 \\
L & 53 & 2 & 0 \\
\hline
\end{tabular}

\section{DISCUSSION}

The communities of small rodents in the two lakeside study areas differ in respect of certain characters. The community by Lake Sniardwy is more diversified than that by Lake Euknajno, and this is expressed in the Shannon-Wiener index values (Table 2). This difference and also the greater density of whole community in the majority of seasons by Lake Sniardwy than by Lake Euknajno (Fig. 1) would appear to be due to the different character of the respective habitats. The habitat of the edge of Lake Sniardwy is more mosaic in character, which is more favourable to settlement and attainment of higher population numbers of small rodents (especially voles). Confirmation of this has been supplied by numerous authors (Wiens, 1976; Hansson, 1979).

Differences in the species composition of the two rodent communities examined may also be due to the differences in the habitats bordering the lakeside zones, and this would appear to account for, e. g., the more frequent occurence of $A$, $a$. at the edge of Lake Euknajno, which is surrounded by agricultural land, than the edge of Lake Sniardwy, which is surrounded by forest (Fig. 2, 3). According to Zejda (1967) A. a. is connected with agrocenoses and occurs most numerously on the lakeside zones bounded by cultivated fields.

In the more diversifield habitat of the edge of Lake Sniardwy C. g. reaches greater density than by Lake Euknajno and the annual course of variations in numbers (Fig. 1) is typical of populations of this species in Poland (e. g., Andrzejewski, 1963; Gliwicz, 1975). The absence of such a typical course of variations in numbers of $C . g$. on the edge of Lake Łuknaj $\mathrm{o}$ and maintenance (particularly during the first study year) 
from spring to autumn of population density on a uniform level (Fig. 1) may suggest that $C . g$. does not find suitable conditions for normal population development in this area. This assumption is supported by papers: by Holišova (1972) and Pelikán (1975), in which the authors suggest that conditions prevailing in this type of habitat are unfavourable and close to the limits of tolerance of $C . g$. This is due chiefly to poor food supply, particularly in the second half on the growing season (Holišova, 1972).

Some authors consider that $A$. $a$. is an important element in the community of small mammals living on the edge of lakes and ponds, on account of its relatively strong and lasting connection with this type of habitat (Kolyushev, 1953; Popov, 1960; Zejda, 1967). Reedbelts are characterized by a particularly great proportion of $A$. a. (Raczyński et al., 1983). Chełkowska (1969) states that in wooded land osier beds are one of the most favourable biotopes for $A . a$., in which this species settles and reproduces and in turn spreads to other habitats as their numbers increase. The results of the present study do not, however, fully confirm this. Although $A$. a. occurs in considerable densities on the edge of Lake Sniardwy, this applies only to autumn - during the season of intensive migration (Fig. 2,3) and on the edge of Lake Łuknajno almost total exchange of individuals in the population takes place from season to season. These facts lead to the assumption that $A$. $a$. is only periodically connected with lakesides and migrates there from other habitats.

The periodical appearance on the edges of lakes of other rodent species (Fig. 2), and almost complete exchange of their individuals from season to season, form evidence of the absence of any lasting connection of these species with the habitat of lakesides.

The permanent accurrence of $M$. o. population on the edge of Lake Sniardwy forms a separate case (Fig. 3). Data in literature show that the lakeside habitat, covered by reedbelts and shrubs, very much waterlogged, with vegetation growing in hummocks, forms very favourable conditions for the existence of $M$. o. (Karaseva et al., 1957; Raczyński et al., 1983).

The dry zone is most numerously occupied by small rodents (Table 3 ). C. $g$. is most strongly "attached" to this area, and this species forms the greatest percentage in the "land" group (Fig. 6), with the centres of their home ranges situated, in the majority of cases, in the dry part of the lakeside (Fig. 4).

The presence in almost all study seasons in both lakesides of rodents caught either solely in the immersed zone ("water" group) or simultaneously in both immersed and exposed zone ("land-water" group) (Table 3) shows that these animals make use of all parts of the lakesides, including those under water. The boundary between water and land 
does not thus form a sharply-demarcated limit of occurrence for these typically land mammals.

The vast majority of rodents in the "water" group consists of individuals periodically appearing in the lakeside area (Fig. 6) and among C. g. - almost only individuals recorded in the study area in one study season only (Fig. 9). Among representatives of C. g., A. a., and A. f., individuals of the "water" group are characterized in the majority of cases by the lowest number of captures per individual (Fig. 7). This is a characteristic of individuals occupying a low position in the social hierarchy of the population (Andrzejewski et al. 1959). The absence of C. g. pregnant females in "water" group suggests that they do not participate in reproduction (Fig. 8). They are not, however, the youngest animals, since they are not distinguished from others in respect of mean body weight (Table 4 ).

Individuals occupying the lakeside zone covered with water thus possess certain charateristios of "poorer" individuals in the population and the whole community. It may be that their entry into and stay in lakeside areas covered by water is the effect of "saturated" dispersal in the sense given by Lidicker $(1962,1975)$, as the result of which animals "poorer" in certain respects in the population are obliged to migrate and search for places to settle in. It may therefore be that rodents recorded in the immersed parts of the lakeside zone form the migrating part of the population, and their being in this part of the lakeside is the effect of the phenomenon, well known during peak population numbers, of the appearance of representatives of the species also in habitats which are not their typical ones (Aulak, 1970). Confirmation for this assumption is provided by the fact that the "water" group is the most numerous in the lakesides in the autumn (Table 3) i. e., during the season of maximum numbers and most intensive migration.

For at least certain species of rodents, simultaneous use of both dry and underwater parts of the lakeside zone may be favourable. This is shown by the situation of centres of home ranges belonging to representatives of $A, a$. near the water line (Fig. 4). The number of captures/ individual was higher for representatives of $S . g ., A$. a., and $A$. f. from the "land-water" group than for individuals belonging to other groups (Fig. 7), which is a characteristic of population dominants (Andrzejewski et al., 1959). Individuals of C. $g$. from the "land-water" group were characterized by larger home ranges than other bank voles (Fig. 10). This property also is a characteristic of individuals dominating in a population (e. g., Gliwicz, 1979).

A constant component of the community of small mammals in the lakesides examined are insectivores. In this group of animals also typi- 
cally land species such as $S$. $a$. and $S$. $m$. make use bath of emergent and submergent parts of the lakeside (Table 5). As in the case of land rodents, the boundary line between land and water does not form a sharply-demarcated limit of occurrence for land insectivores.

\section{REFERENCES}

1. Andrzejewski R., 1963: Processes of incoming, settlement and disappearance of individuals and variations in the numbers of small rodents. Acta theriol., 7: $169-213$.

2. Andrzejewski R., Petrusewicz K. \& Walkowa W., 1959: Preliminary report of results obtained with a living traps in a confined population of mice. Bull. Acad. Pol. Sci. Cl. II, 7: 367-371.

3. Aulak W., 1970: Small mammals communities in Białowieża National Park. Acta theriol., 15: 465-515.

4. Bauer K., 1960: Die Saugetiere des Neusiedlersee-Gebietes. Bonn. zool. Beitr., 11: $141-344$.

5. Chełkowska H., 1969: Numbers of small rodent in five plant associations. Ekol. pol, A, 17: 848-854.

6. Gliwicz J., 1975: Age structure and dynamics of numbers in island population of bank vole. Acta theriol., 20: 57-59.

7. Gliwicz J., 1979: Struktura wiekowa a organizacja socjalna populacji gryzoni. Wiad. ekol., 25: 9-17.

8. Hansson L., 1979: On the importance of landscape heterogeneity in northern regions for the breeding population densities of homeotherms: a general hypothesis. Oikos, 33: 182-189.

9. Holišova V., 1972: The food of Clethrionomys glareolus in a reedswamp. Zool. listy, 21: 293-307.

10. Holišova V., 1975: The food eaten by rodents in reedswamps of Nesyt fishpond. Zool. listy, 24: 223-237.

11. Karaseva E. V., Narskaya E. V. \& Bernstein A. D., 1957: Polevka ekonomka obitajušcaja v okresnostiach ozera Nero Jaroslaviskoj oblasti. Biull. Mosk. Občs. Isp. Prir., 62: 5-18.

12. Kolyushev I. I., 1953: Short outline of the fauna of rodents of Transcarpatian Region. Naučnyje Zapiski Užgorod. Gos. Univ., 8: 143-158 [In Russian].

13. Lidicker W. Z., Jr., 1962: Emigration as a possible mechanism permitting the regulation of population denisity below carrying capacity. Amer. Nat., 96: $29-33$.

14. Lidicker W, Z. Jr., 1975: The role of dispersal in the demography of small mammals. [In: "Small mammals: their productivitw and population dynamics", Eds. P. B. Golley, K. Petrusewicz, L. Ryszkowski]. IBP, 5, Cambridge Univ. Press: $103-128$.

15. Mazurkiewicz M., 1969: Eliptical modification of the home range pattern. Bull. Acad. Pol. Sci., Cl. II, 17: 427-431.

16. Mazurkiewicz M., 1970: Analysis of home range direction based on the catchmark-release method. Bull. Acad. Pol. Sci., Cl. II, 19: 465-468.

17. Obrtel R., 1975: Animal food eaten by rodents in the reed swamps of Nesyt Pond. Zool. Listy, 24: 325-334. 
18. Pelikán J., 1975: Mammals of Nesyt fishpond, their ecology and production. Acta sci. nat., 9: $1-40$.

19. Pelikán J., 1978: Mammals in the reed swamp ecosystem. [In: "Pond littoral ecosystems. Structure and functioning", Eds. D. Dykyjova, J. Kvet]. Ecological studies 28, Springer Verlag: 257-265, Berlin, Heidelberg, New York.

20. Pelikán J. \& Hodkova Z., 1977: On the ecology of mammals on Nesyt fishpond during a spell of extreme drought. Folia zool., 26: 99-113.

21. Pieczyńska E., 1972: Ecology of eulittoral zone of lakes. Ekol. pol. A, 22: $637-732$.

22. Pieczyńska E., 1975: Ecological interaction between land and-littoral zones of lakes. [In: "Coupling of land and water system", Ed. A. D. Hasler]. Ecological Studies 10, Springer Verlag: 263-276, Berlin, Heidelberg, New York.

23. Popov V. A., 1960: Mammals of the Volga-Kama region (Insectivores, bats, rodents). Izd. AN SSSR: 1-468. Kazań. [In Russian].

24. Pucek Z., 1969: Trap response and estimation of numbers of shrews in removal catches. Acta theriol., 14: 403-426.

25. Raczyński J., Fedyk S., Gębczyńska Z. \& Pucek M., 1983: Drobne ssaki środkowego i dolnego basenu Biebrzy. Zesz. probl. Postępów Nauk. roln., 255: 297-328.

26. Wiens J. A., 1976: Population responses to patchy environments. Ann. Rev. Ecol. Syst., 7: 81-120.

27. Zejda J., 1967: Habitat selection in Apodemus agrarius (Pallas, 1771), (Mammalia, Muridae) on the border of the area of its distribution. Zool. Listy, 16: $15-24$.

Accepted, Febrauary 18, 1985.

Anna KOZAKIEWICZ

\section{ZESPOEY DROBNYCH SSAKÓW POBRZEŻY JEZIOR}

Streszczenie

Badania prowadzono $\mathrm{w}$ okolicach Mikołajek na dwóch powierzchniach badawczych, obejmujących wynurzone oraz zalane przez wodę fragmenty pobrzeży jezior Łuknajno i Sniardwy. Zastosowano metodę CMR. Pułapki ustawione były w stałych punktach w szachownicy $15 \times 15 \mathrm{~m}$ na powierzchniach, których wielkość zależała od poziomu wody $\mathrm{w}$ jeziorze i wynosiła nad jeziorem Łuknajno $2,8-3,3$ ha, nad jeziorem Sniardwy 0,9-1,8 ha.

$\mathrm{Na}$ pobrzeżu jeziora Łuknajno badania rozpoczęto w lutym 1977 r. i zakończono w lutym 1979 r., natomiast na pobrzeżu jeziora Sniardwy rozpoczęto je w lipcu 1977 r. a zakończono w kwietniu 1979 r., odławiając zwierzęta przez 10 dni, nad jeziorem Łuknajno czterokrotnie w ciągu każdego roku (luty, kwiecień, czerwiec-lipiec, wrzesień), a nad jeziorem Sniardwy trzykrotnie w ciągu każdego roku (kwiecień, lipiec, wrzesień).

Ogółem w czasie badań odłowiono na obu powierzchniach 902 osobniki drobnych gryzoni (Tabela 1), które zrealizowały 4350 złowień oraz 235 osobników owadożernych (Tabela 1).

Na pobrzeżach jezior stwierdzono stałe występowanie zespołów drobnych ssaków 
(gryzoni i owadożernych) (Ryc. 2, Tabela 5). Gatunkiem stałym i dominującym w obu zespolach był Clethrionomys glareolus, poza tym na pobrzeżu Sniardw stale występował Microtus oeconomus, Pozostałe gatunki na pobrzeżach występowały okresowo (Ryc. 2).

Zmiany zagęszczenia populacji C. glareolus na dwóch badanych pobrzeżach przebiegały odmiennie lecz na ogół w sposób typowy dla tego gatunku (Ryc. 1). Można sądzić, że nornica ruda nie znajduje w środowisku pobrzeża jeziora Łuknajno odpowiednich warunków dla normalnego rozwoju populacji.

Stwierdzono, że zarówno gryzonie. jak i owadożerne łowiły się we wszystkich częściach badanych pobrzeży (łącznie z zalanymi przez wodę) (Tabele 3,5 ). Granica wody i lądu nie stanowi więc dla nich ostrej granicy występowania.

Najwięcej gryzoni i owadożernych odłowiono w części wynurzonej pobrzeży. Wśród gryzoni strefę suchą najintensywniej wykorzystywała C. glareolus i w tej strefie położona była ogromna większość jej centrów areałów osobniczych (Ryc. 4).

Gryzonie, które odławiały się na terenie zalanym przez wodę zaliczono do dwóch grup: grupy „wodnej” (zwierzęta lowiące się wyłącznie w zanurzonej strefie pobrzeża), grupy „lądowo-wodnej” (zwierzęta łowiące się równocześnie w części zalanej i wynurzonej). Trzecią grupę stanowiły gryzonie odławiające się wyłącznie w strefie wynurzonej nazwane grupą ,lądową".

Grupa „wodna" składała się głównie z osobników gatunków okresowo pojawiających się na terenie pobrzeży (Ryc. 6). Łowność osobników C. glareolus, Apodemus agrarius i Apodemus flavicollis tej grupy była najniższa w porównaniu z grupami "lądową" i „lądowo-wodną" (Ryc. 7). Ponadto nornice z grupy „wodnej” przebywały na powierzchni w większości przypadków tylko przez jeden sezon badawczy (Ryc. 9). Brak było wśród nich samic ciężarnych (Ryc. 8). Tak więc osobniki grupy „wodnej” miały pewne cechy osobników „gorszych” w populacji (i w całym zespole). Zasugerowano, że jest to frakcja migrantów, zasiedlająca w okresach szczytów populacyjnych środowiska nietypowe dla gatunku.

Wydaje się, że równoczesne wykorzystywanie suchej i zalanej przez wodę części pobrzeża jest korzystne, dla niektórych przynajmniej gatunków gryzoni. Na przykład centra areałów osobniczych $A$. agrarius koncentrowaly się na badanych pobrzeżach na granicy wody (Ryc. 4). Osobniki z grupy „lądowo-wodnej” wykazywały pewne cechy dominantów populacyjnych - charakteryzowały się wysoką łownością (C. glareolus i A. flavicollis) (Ryc. 7) i dużymi areałami osobniczymi (Ryc, 10). 